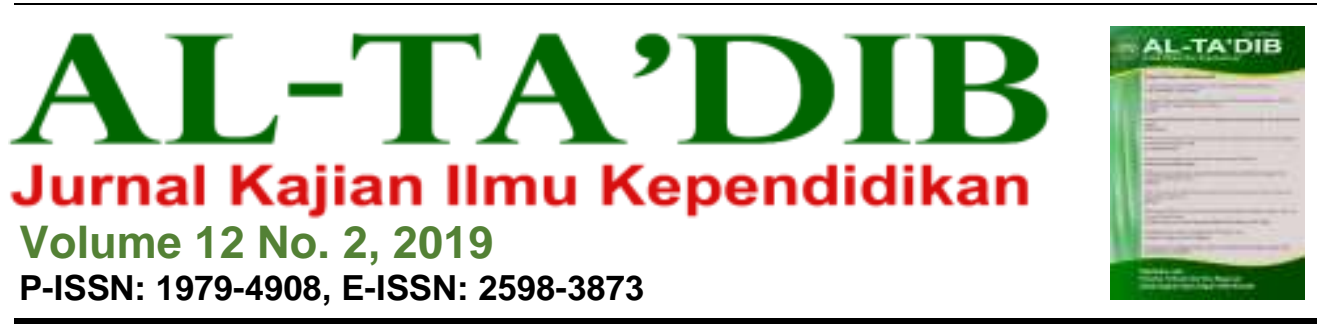

\title{
Pelaksanaan Metode Karyawisata dalam Pembelajaran Pendidikan Agama Islam di Taman Kanak-Kanak
}

\author{
Suridah $^{1}$, Dimas Fajar ${ }^{2}$, Fahrurozi $^{3}$, Rani Anggraini ${ }^{4}$, Ruhiyati Ulfa ${ }^{5}$, Sonia $^{6}$ \\ ${ }^{1}$ Universitas Islam Riau, Pekanbaru, Indonesia. E-mail: suridah@student.uir.ac.id \\ ${ }^{2}$ Universitas Islam Riau, Pekanbaru, Indonesia.E-mail: dimasfajar@student.uir.ac.id \\ ${ }^{3}$ Universitas Islam Riau, Pekanbaru, Indonesia. E-mail: fahrurozi@ student.uir.ac.id \\ ${ }^{4}$ Universitas Islam Riau, Pekanbaru, Indonesia. E-mail: ranianggraini@ student.uir.ac.id \\ ${ }^{5}$ Universitas Islam Riau, Pekanbaru, Indonesia. E-mail: ruhiyati@ student.uir.ac.id \\ ${ }^{6}$ Universitas Islam Riau, Pekanbaru, Indonesia.
}

\section{INFORMASI ARTIKEL}

Kata Kunci:

PAI; pembelajaran; pendidikan; metode karyawisata; TK

\section{Cara Mensitasi:}

Suridah, Fajar, D.,

Fahrurozi, Anggraini, R., Ulfa, R., \& Sonia. (2019).

Pelaksanaan Metode

Karyawisata dalam Pembelajaran Pendidikan Agama Islam di Taman Kanak-Kanak. $A l$ Tadib:Jurnal Kajian Ilmu Kependidikan, 12(2), 294305.

\section{DOI:}

http://dx.doi.org/10.31332/ atdbwv12i2.1341

\begin{abstract}
ABSTRAK
Penelitian studi kasus ini bertujuan untuk mengetahui penerapan metode karyawisata dan permasalahannya dalam pembelajaran Pendidikan Agama Islam di salah satu taman kanak-kanak di Pekanbaru. Teknik pengumpulan data menggunakan observasi dan wawancara. Data dianalisis secara kualitatif menggunakan tahapan data cleaning, transcribing, coding and categorizing, dan interpreting. Hasil penelitian menunjukkan bahwa pelaksanaan metode karyawisata dalam pembelajaran pendidikan agama Islam di taman kanak-kanak harus terjadwal dan sesuai prosedur. Tema yang diusung harus diintegrasikan dengan ajaran Islam. Lokasi yang dipilih untuk karya wisata harus dapat membantu peserta didik memeroleh pengalaman langsung dari obyek yang mereka lihat. Kompetensi anak yang nampak dalam metode ini adalah potensi dan kreatifitas, menghargai pekerjaan dan tugas orang lain dan membentuk sikap bertanggung jawab.
\end{abstract}




\section{ARTICLE INFO}

Keywords:

Education; field trip method; Islamic religion education; kindergarten; learning

How to cite:

Suridah, Fajar, D., Fahrurozi, Anggraini, R., Ulfa, R., \& Sonia. (2019).

Pelaksanaan Metode

Karyawisata dalam Pembelajaran Pendidikan Agama Islam di Taman

Kanak-Kanak. Al-

Tadib:Jurnal Kajian Ilmu Kependidikan, 12(2), 294305.

DOI:

http://dx.doi.org/10.31332/

atdbwv12i2.1341

\section{ABSTRACT}

This case study discusses the implementation of field trip method in Islamic religion education learning and its challenges in one of kindergartens in Pekanbaru. Data collection techniques are observation and interviews. Data were analyzed qualitatively using data cleaning, transcribing, coding and categorization, and interpretation. The results show that the implementation of the field trip method in the study of Islamic religion in the kindergarten should be scheduled and based on procedure. The theme should be integrated with Islamic lessons. The choice of locations should help students gain direct experience of the objects they see. This method coud help develop the students' potential and creativity, appreciation of other people's works and tasks, and responsibility.

\section{Pendahuluan}

Metode karyawisata atau field trip ialah metode mengajar yang dilaksanakan dengan mengajak peserta didik ke suatu tempat atau objek tertentu di luar sekolah untuk mempelajari atau menyelidiki sesuatu seperti meninjau pabrik sepatu, bengkel mobil, toko serba ada, peternakan, perkebunan, dan lapangan bermain (Roestiyah dalam Yati, 2016). Winarno dalam Shidqiyah (2019) mengatakan bahwa metode karyawisata atau field trip adalah metode belajar dan mengajar dimana peserta didik dengan bimbingan guru diajak untuk mengunjungi tempat tertentu dengan maksud untuk belajar. Berbeda halnya dengan tamasya, di mana seseorang pergi untuk mencari hiburan semata, field trip sebagai metode belajar mengajar lebih terikat oleh tujuan dan tugas belajar. Sedangkan menurut Sagala dalam Saputra (2006) metode field trip atau karyawisata adalah pesiar (ekskursi) yang dilakukan oleh para peseta didik untuk melengkapi pengalaman belajar tertentu dan merupakan bagian integral dari kurikulum sekolah.

Metode karyawisata, dalam penelitian Adelia dalam Saputri (2017), diuraikan sebagai kegiatan belajar mengajar guru dan siswa di luar kelas 
dengan menggunakan media pembelajaran yang konkret dan memahami lingkungan yang ada di sekitarnya. Adapun contoh media yang sesuai dengan materi pelajaran, situasi, dan kenyataan dari pembelajaran di luar kelas adalah sebagai berikut: (1) berbagai aneka satwa (binatang), sungai, laut, tumbuhtumbuhan, dan matahari yang ada di luar sekolah; (2) kelompok-kelompok masyarakat yang ada di luar sekolah; (3) tempat-tempat ibadah di luar sekolah; (4) halaman sekolah sebagai media pembelajaran berbagai macam mata pelajaran; (5) warung makan, toko, dan pasar; dan, (6) permainan anak, seperti seluncuran, ayunan, jungkat-jungkit, dan lain-lain.

Penggunaan metode karya wisata pada anak TK akan sangat membantu untuk meningkatkan kreativitas dan apresiasi mereka karena pada dasarnya anak TK adalah anak-anak yang memasuki tahap perkembangan kognitif "operasional konkrit". Artinya, dalam masa seperti ini anak-anak lebih cepat mendapatkan pengetahuan dari sebuah pengalaman. Kegiatan belajarmengajar di luar kelas juga dapat mendorong para siswa mengembangkan sikap kemandirian. Ketika mereka belajar di luar kelas, sebenarnya mereka sedang menghilangkan sikap ketergantungan pada orang lain, minimal ketergantungan terhadap guru.

Kegiatan di luar kelas akan membuat guru tidak banyak berbicara atau aktif menerangkan, sebagaimana saat mengajar di dalam kelas, namun tetap tidak keluar dari esensi dan tujuan belajar. Dalam memberi materi pelajaran yang akan diberikan di luar kelas, banyak faktor atau pertimbangan dalam memilih objek pembelajaran yang harus dipikirkan. Menurut Adelia dalam Saputri (2017), faktor-faktor tersebut diantaranya adalah sebagai berikut: a) sesuai dengan kurikulum yang berlaku, b) mudah dijangkau, c) tidak membutuhkan biaya mahal, d) memiliki potensi untuk digunakan pada berbagai materi, dan e) tidak asing bagi guru. Kegiatan belajar di luar kelas dapat pula diterapkan dalam pembelajaran pendidikan agama Islam.

Menurut Daradjat (2017), pendidikan agama Islam adalah usaha berupa bimbingan dan asuhan terhadap peserta didik agar kelak setelah selesai pendidikannya, mereka dapat memahami dan mengamalkan ajaran agama Islam serta menjadikannya sebagai pandangan hidup. Pendidikan agama Islam mempunyai banyak definisi, diantaranya menurut Tafsir (2011) pendidikan agama Islam adalah pendidikan yang berlandaskan ajaran Islam. Arifin (2008) juga mengemukakan bahwa pendidikan agama Islam adalah usaha orang dewasa muslim yang bertaqwa secara sadar mengarahkan dan membimbing pertumbuhan dan perkembangan fitrah (kemampuan dasar) peserta didik melalui ajaran Islam ke arah titik maksimal pertumbuhan dan perkembangan.

Dengan demikian, pendidikan agama Islam mengandung makna upaya pendidikan yang dilaksanakan menurut ketentuan Islam menyangkut penyesuaian materi, metode, dan berbagai komponen pendidikan lainnya, serta memperbaiki potensi manusia untuk meningkatkan pengabdian diri 
kepada Allah SWT. Pendidikan agama Islam merupakan pendidikan yang ditujukan untuk membentuk perilaku manusia yang mengabdi kepada Allah SWT. Pendidikan agama Islam juga merupakan proses pembelajaran untuk mencapai tingkat keimanan yang kokoh dari waktu ke waktu berbasis ilmu dan keilmuan yang disertai dengan amal sholeh. Selain itu, pendidikan berbasis Islam akan membentuk akhlak mulia.

Pendidikan agama Islam telah sejalan dengan tujuan pendidikan nasional. Dalam Undang-Undang No. 20 tahun 2003 disebutkan bahwa pendidikan nasional berfungsi untuk mengembangkan kemampuan dan membentuk watak serta peradaban bangsa yang bermartabat dalam rangka mencerdaskan kehidupan bangsa bertujuan untuk mengembangkan potensi peserta didik agar menjadi manusia yang beriman dan bertaqwa kepada Tuhan Yang Maha Esa, berahlak mulia, sehat, berilmu, cakap, kreatif, mandiri dan menjadi warga negara yang demokratis dan bertanggung jawab (Usaha, Inah, \& Kadir, 2018).

Karyawisata dalam pembelajaran PAI menekankan pada penyajian pelajaran yang dilaksanakan dengan mengajak peserta didik ke suatu tempat atau objek tertentu di luar sekolah dengan mengamalkan dan menerapkan nilai ajaran agama Islam. Metode ini berguna untuk mempelajari atau untuk menyelidiki sesuatu dengan melakukan pengamatan langsung melalui panca indera untuk memperoleh pengalaman dari objek yang dilihatnya sesuai dengan tujuan pembelajaran yang telah ditetapkan. Karyawisata memilki peran penting dalam proses pembelajaran karena dengan karyawisata peserta didik dapat mengembangkan pontesi dan kreatifitas yang mereka miliki didukung oleh nilai-nilai Islam.

Penelitian tentang metode karyawisata telah banyak dilakukan, namun pelaksanaannya di Taman Kanak-Kanak masih sangat terbatas utamanya dalam pembelajaran PAI. Oleh karena itu, penelitian ini mengeksplorasi pelaksanaan metode karyawisata dalam pembelajaran PAI di salah satu TK di Pekanbaru. Penelitian ini menganalisis nilai-nilai agama dan moral yang masuk dalam pembelajaran PAI. Hasil penelitian ini baik secara teori maupun praktik diharapkan dapat memberi kontribusi bagi seluruh sekolah yang menerapkan integrasi nilai-nilai Islam di dalam proses pembelajaran secara umum.

Hasil penelitian ini diharapkan dapat dimanfaatkan oleh guru untuk membantu mereka terus berinovasi menggunakan berbagai macam model pembelajaran, strategi atau media pembelajaran yang dapat merangsang minat, kemandirian dan keaktifan siswa dalam proses pembelajaran. Dengan penerapan model pembelajaran karyawisata, siswa diharapkan mampu belajar memecahkan suatu masalah secara mandiri dan mengembangkan sikap percaya diri. Model pembelajaran karyawisata dapat dijadikan sebagai salah satu alternatif pembelajaran di luar kelas agar siswa lebih memahami materi 
yang dipelajari, lebih aktif, melatih daya tangkap, dan saling membantu satu sama lain.

\section{Metode Penelitian}

Penelitian ini adalah penelitian kualitatif dengan pendekatan studi kasus. Subjek penelitian ini adalah guru TK Islam Al-Fitrah Pekanbaru. Objek penelitian adalah pelaksanaan metode karyawisata dalam pembelajaran PAI. Teknik pengumpulan data berupa observasi terhadap proses pembelajaran dan wawancara dengan kepala sekolah dan guru di TK Al-Fitrah. Wawancara dilakukan terhadap responden secara langsung (tatap muka) untuk mendapatkan informasi mendalam terkait data yang dapat menjelaskan rumusan masalah dalam penelitian ini. Instrumen wawancara penelitian ini dikembangkan dari kajian teori penggunaan dan pelaksanaan metode karyawisata dalam pembelajaran. Teknik analasis data yang digunakan adalah: Data cleaning, yaitu proses untuk memastikan sekumpulan data sudah benar dan akurat; Transcribing, yaitu proses yang mengalih bentuk dari rekaman audio menjadi rekaman tertulis, sehingga peneliti lebih fokus dalam meneliti yang berkaitan dengan analisis sosiolinguistik dan wancana; Coding and categorizing, yaitu mengklasifikasikan jawaban dari responden menurut kriteria tertentu; Interpreting adalah proses dimana peneliti menggunakan kemampuan memahami maksud responden dan mengungkapkan maknanya secara tepat. Dalam hal ini peneliti juga menunjukkan kemampuannya untuk mengambil keputusan secara cepat dan langsung demi ketepatan hasil penelitian.

\section{Hasil dan Pembahasan}

\subsection{Waktu dan Prosedur Pelaksanaan Karyawisata}

Berdasarkan observasi dan wawancara, pembelajaran PAI dengan menggunakan metode karyawisata telah dilaksanakan secara rutin. Karyawisata dapat dilakukan dalam waktu singkat, beberapa jam saja ataupun cukup lama sampai beberapa hari. Menurut responden, idealnya, karyawisata dilakukan sebulan sekali dan pelaksanaan karyawisata disesuaikan dengan tema yang diajarkan. Akan tetapi, pada kenyataannya pembelajaran ini biasanya hanya bisa dilakukan dua sampai tiga kali dalam satu tahun pelajaran. Metode ini dirancang terlebih dahulu oleh pendidik dan diharapkan siswa membuat laporan dan didiskusikan bersama dengan peserta didik yang lain serta didampingi oleh pendidik, yang kemudian dibukukan. Hasil karyawisata dibawa anak-anak ke sekolah dan sebagian dibawa ke rumah untuk diperlihatkan pada orang tua. 
Karyawisata sebagai metode mengajar memerlukan langkah-langkah yang baik, diantaranya; persiapan dan perencanaan, pelaksanaan dan tindak lanjut. Persiapan karyawisata oleh guru secara umum ada tujuh hal.

Pertama, guru menetapkan sasaran yang diprioritaskan sesuai tema kegiatan beajar yang dipilih. Guru menetapkan beberapa kriteria penting dalam menetapkan sasaran karyawisata. Sasaran karyawisata yang ditetapkan secara relatif lebih menunjang peningkatan aspek perkembangan anak TK yang ingin dicapai. Sasaran karyawisata mudah dijangkau oleh anak-anak yang masih muda usia, tidak melelahkan, dan resiko bahayanya kecil.

Kedua, guru mengadakan hubungan dan pengenalan medan sasaran karyawisata. Pendidik telah benar-benar mengenal sasaran karyawisata yang sudah ditetapkan. Sebelum membawa anak TK ke sasaran karyawisata, terlebih dahulu pendidik mendatangi sasaran untuk mendapat informasi langsung dan mengamati secara khusus kemungkinan pengalaman belajar yang akan diperoleh anak di tempat itu dan aspek-aspek penting apa yang dapat ditunjukkan kepada anak sesuai dengan perhatian dan minat mereka.

Ketiga, guru merumuskan progam kegiatan melalui karyawisata. Ada lima pertimbangan yang diperhatikan oleh pendidik untuk memutuskan penggunaan metode karyawisata pada anak TK yakni: tujuan pendidikan yang ingin dicapai, kesesuaian karyawisata itu, banyaknya waktu yang harus disediakan, biaya yang dibutuhkan, antisipasi bahaya yang mungkin terjadi dan cara-cara mengatasinya.

Keempat, guru menyiapkan bahan dan alat yang diperlukan untuk karyawisata. Untuk merancang karyawisata yang baik, pendidik menyusun daftar bahan dan alat apa saja yang diperlukan. Kelima, guru menetapkan tata tertib berkaryawisata. Kegiatan belajar tidak akan terjadi bila tidak ada tata tertib dalam berkaryawisata. Penetapan tata tertib diarahkan pada pengendalian diri dan memungkinkan anak memahami dan menghayati tingkah laku yang dapat diterima kelompok. Tata tertib memberi batasan apa yang boleh dilakukan dan tidak boleh dilakukan anak bagi kebaikan bersama dalam melaksanakan karyawisata.

Keenam, ada permintaan izin dan partisipasi orang tua anak. Pendidik menginformasikan kepada orang tua tentang rencana karyawisata. Informasi itu dimaksudkan agar orang tua mengetahui tentang kegiatan tersebut, bagi orang tua yang berminat atau memperoleh giliran agar ikut berpartisipasi dalam pelaksanaan karyawisata. Di samping itu, perlu izin orang tua untuk mengikuti karyawisata.

Ketujuh, persiapan pendidik di kelas. Kegiatan karyawisata merupakan batu loncatan untuk melakukan kegiatan belajar dengan menggunakan metode yang lain di kelas atau merupakan puncak kegiatan setelah melakukan kegiatan belajar di kelas, maka pendidik perlu merancang kegiatan belajar di kelas sebagai batu loncatan untuk melaksanakan kegiatan karyawisata. 


\subsection{Tema dan Tempat Pelaksanaan Karyawisata}

Berdasarkan observasi yang dilakukan pada TK Al- Fitrah Pekanbaru dan dari hasil wawancara dengan guru, tema dalam pembelajaran di TK Islam Al Fitrah dibagi ke dalam beberapa tema, antara lain tentang hewan, tumbuhan dan mahluk hidup lainnya. Tempat pelaksanaan karyawisata di museum, kawasan agrowisata, kebun sayur, kebun binatang, dan tempat kuliner.

Terkait kegiatan belajar mengajar, karyawisata berarti siswa mempelajari secara langsung suatu obyek di tempat mana obyek tersebut berada. Djamarah dan Zain (2006) menegaskan bahwa pada saat belajar mengajar, peserta didik perlu diajak keluar sekolah untuk meninjau tempat tertentu atau objek yang lain. Hal itu bukan sekedar rekreasi tetapi untuk belajar atau memperdalam apa yang telah didapatkan di sekolah dengan melihat kenyataan di lingkungan sekitar dan di komunitas. Oleh karena itu, teknik karyawisata merupakan cara mengajar yang dilaksanakan dengan mengajak peserta didik ke suatu tempat atau objek tertentu di luar sekolah (Winarno dalam Shidqiyah, 2019) untuk mempelajari atau menyelidiki sesuatu di luar lingkungan sekolah. Dengan karyawisata para peserta didik diajak langsung untuk mengamati manusia, hewan, tumbuh-tumbuhan, dan benda-benda lainnya (Adelia dalam Saputri, 2017).

Aktivitas yang utama dalam karyawisata adalah proses pembelajaran. Dalam pembelajaran yang menerapkan metode karyawisata guru berfungsi sebagai pembimbing. Guru memfasilitasi proses pembelajaran dan menyediakan sumber belajar yang memadai bagi siswa. Kemudian, guru juga mengawasi jalannya kegiatan pembelajaran agar dapat terlaksana secara efektif.

\subsection{Pembelajaran Pendidikan Agama Islam dengan Metode Karyawisata}

Dalam pembelajaran PAI di TK Al-Fitrah digunakan metode karyawisata sesuai dengan tema pembelajaran yang akan dilaksanakan. Hal ini sesuai dengan hasil wawancara dengan guru responden yang menyatakan bahwa metode karyawisata dalam pembelajaran PAI masih jarang ia gunakan karena metode ini menyesuaikan pada tema yang telah ditentukan. Dalam menerapkan metode karyawisata, guru tersebut telah melakukannya sesuai prosedur, yakni terlebih dahulu mengajak peserta didik ke suatu objek tertentu, mempelajari atau menyelidiki sesuatu, melakukan pengamatan langsung, dan melalui panca indera.

Metode ini juga membuat siswa lebih memahami pelajaran karena mereka dihadapkan langsung dengan objek pembelajaran, seperti dalam materi "mengenal dan mensyukuri ciptaan Tuhan". Dalam materi ini, siswa ditunjukkan bagaimana ciptaan Tuhan secara langsung sehingga siswa-siswa merasa takjub dan pengalaman itu akan membekas. 
Penelitian ini menemukan pula bahwa melalui penggunaan metode karyawisata dalam pembelajaran PAI terdapat beberapa variabel yang dapat diperjelas untuk mempermudah guru PAI dalam menjalankan metode ini dalam pembelajaran. Pertama, cara penyajian pelajaran. Cara penyajian ini merupakan langkah-langkah penting yang dipergunakan guru PAI untuk mensukseskan dirinya dalam proses pembelajaran PAI. Hal yang disajikan oleh guru adalah materi PAI. Bila dikaitkan dengan cara penyajian, hal ini menggambarkan bahwa metode karya wisata tersebut dipergunakan oleh guru PAI dalam mengajarkan materi pembelajaran. Kedua, mengajak peserta didik ke suatu objek tertentu. Dalam menggunakan metode eksperimen, guru PAI harus mengajak para peserta didik pada suatu objek tertentu. Disini guru sudah harus memperhatikan hal-hal penting terkait dengan kondisi objek yang akan dijadikan tempat karyawisata. Metode karyawisata menuntut guru dalam proses pembelajarannya keluar dari kelas yang sebenarnya. Pembelajaran dengan metode ini dilakukan diluar kelas yaitu pada suatu objek tertentu yang memang sesuai dengan materi pembelajaran yang telah ditetapkan. Ketiga, melalui panca indera. Panca indera menjadi salah satu aspek penting dalam proses penggunaan metode karyawisata. Panca indera digunakan dengan maksimal untuk merasakan dan memahami objek yang sedang diamati. Hal ini menggambarkan bahwa pelibatan panca indera menjadi pendukung utama dalam menjalankan metode karyawisata oleh guru PAI dalam pembelajarannya.

Metode karyawisata dalam pembelajaran pendidikan agama Islam ini secara umum dapat dilacak pada sumber ajaran Islam yang utama pada Alquran.

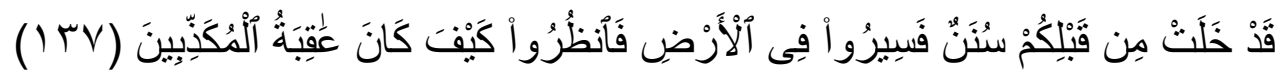

Artinya: Sesungguhnya telah berlalu sebelum kamu sunnah-sunnah Allah, karena itu berjalanlah kamu dimuka bumi dan perlihatkanlah bagaimana akibat orang-orang yang mendustakan (rasul-rasul). (QS. Ali Imran, 3:137).

Ayat 137 ini berisi perintah untuk memerhatikan bagaimana keadaan orang-orang terdahulu dan kesudahan mereka. Sesungguhnya telah berlalu sebelum kamu sunnah-sunnah, yakni hukum-hukum kemasyarakatan yang tidak mengalami perubahan. Sunnah tersebut antara lain adalah "yang melanggar perintah-Nya dan perintah Rasul-Rasul Nya akan binasa, dan yang mengikutinya berbahagia", "yang menegakkan disiplin akan sukses", "harihari kekalahan dan kemenangan silih berganti", dan lain-lain. Sunnah-sunnah itu diterapkan Allah SWT demi kemaslahatan manusia, dan itu semua dapat terlihat dengan jelas dalam sejarah dan peninggalan umat-umat yang lalu. Perhatikan dan rekamlah hal tersebut, kalau belum juga kamu pahami dan 
hayati melalui bacaan atau pelajaran sejarah, karena itu, berjalanlah kamu di bumi unuk melihat bukti-buktinya dan perhatikanlah untuk mengambil pelajaran bagaimana kesudahan buruk yang dialami orang-orang yang mendustakan pesan-pesan Allah.

Hal di atas itulah sesungguhnya yang menjadi fokus dan ranah penting yang dapat digali sebagai metode karyawisata adalah "qul siru fi al-ardhi fanzur..." dimana terdapat perintah dari Allah SWT untuk berjalan di bumi dan manusia disuruh untuk memperhatikan isi bumi agar manusia dapat mengambil pelajaran dari apa yang dilihat atau diinderanya. Maka pembelajaran yang dilangsungkan guru PAI ada kalanya harus membawa peserta didik keluar dari ruang kelas dan mengajak mereka ke alam dan memperhatikan alam tersebut agar peserta didik mendapat pelajaran dari apa yang dilihatnya.

Dalam proses memperhatikan tersebut seluruh indera peserta didik terlibat agar dapat memaknai apa yang dilihatnya. Oleh karena itu, metode karyawisata tidak sekedar berjalan-jalan atau wisata saja, akan tetapi harus dibarengi dengan proses pembelajaran di dalamnya agar peserta didik dapat mengambil hikmah dari apa yang dilihat. Kaitan metode karya wisata dengan ayat ini ialah agar pendidik mengajarkan para peserta didik untuk tidak melupakan alam tapi bahkan harus berjalan di muka bumi dengan mengkaji, memperhatikan, dan mempelajarinya secara baik untuk membimbing manusia agar memiliki keimanan yang kokoh pada Allah SWT.

\subsubsection{Kelebihan, Kelemahan dan Manfaat Pembelajaran Pendidikan Agama Islam dengan Metode Karyawisata}

Dari pelaksanaan metode karyawisata di TK AL-Fitrah Pekanbaru ditemukan kelebihan, kelemahan dan manfaat yang diperoleh dari pembelajaran PAI menggunakan metode tersebut. Salah satu kelebihan penggunaan metode karyawisata adalah siswa memperoleh pengalaman baru yang tidak ditemukan di lingkungan tempat tinggalnya maupun di sekolah. Metode ini juga membuat siswa lebih memahami pelajaran karena dihadapkan langsung dengan objek pembelajaran. Dengan menggunakan metode karyawisata, siswa ditunjukkan secara langsung objek-objek pembelajaran dan siswa dapat berpartisipasi secara langsung dengan apa yang sedang dipelajari sehingga siswa memahami materi yang disampaikan gurunya.

Hal ini sejalan dengan paparan yang menguraikan kelebihan metode karyawisata dalam proses pembelajaran PAI bahwa karyawisata menerapkan prinsip pengajaran modern yang memanfaatkan lingkungan nyata dalam pembelajaran. Metode karyawisata dalam pembelajaran menjadi sangat penting dalam setiap pembelajaran PAI karena dapat melibatkan panca indera 
secara langsung atas ciptaan Allah SWT. Ciptaan-Nya yang luas ini bisa diamati secara ilmiah dan berkesinambungan melalui metode karyawisata.

Selain itu, metode karyawisata membuat bahan yang dipelajari menjadi lebih relevan dengan kenyataan dan kebutuhan yang ada di masyarakat. Materi pelajaran yang dipelajari oleh peserta didik dengan menggunakan metode ini akan membuat peserta didik mengetahui dan memahami secara dekat lingkungan sekitar. Disamping itu, pengajaran melalui metode ini dapat lebih merangsang perkembangan kognitif dan daya kreativitas anak karena pembelajaran PAI menggunakan metode ini dapat merangsang daya cipta peserta didik melalui pengamatan langsung.

Dalam metode ini, peserta didik dapat berpartisipasi dalam berbagai kegiatan yang dilakukan oleh para petugas pada objek karyawisata itu. Mereka juga dapat mengalami dan menghayati langsung apa pekerjaan mereka. Peserta didik juga dapat melihat berbagai kegiatan para petugas secara kelompok maupun secara individu dan mereka bisa memahami pekerjaan mereka sehingga akan menambah wawasan mereka. Dalam metode karyawisata, peserta didik dapat bertanya jawab untuk menemukan sumber informasi. Dari objek yang dikunjungi dan ditinjau, peserta didik dapat memperoleh beragam pengetahuan dan pengalaman yang terintegrasi dan terpadu.

Disamping kelebihan, terdapat pula berbagai kekurangan metode karyawisata ini dalam proses pembelajaran PAI. Di TK Al-Fitrah, terdapat beberapa kendala dalam pelaksanaan metode karyawisata, diantaranya adalah masalah pada durasi waktu. Pelaksanaan metode ini membutuhkan waktu khusus sehingga harus ada waktu luang yang dikorbankan. Selanjutnya, lokasi pelaksanaan metode karyawisata kadang jauh dari sekolah sehingga membutuhkan transportasi yang memakan biaya cukup besar sehingga tidak semua siswa bisa mengikutinya.

Kenyataan tersebut sesuai dengan penjelasan tentang kelemahan metode karyawisata dalam pembelajaran PAI. Metode ini memerlukan persiapan yang melibatkan banyak pihak. Penggunaan metode karyawisata membutuhkan pelibatan banyak orang karena peserta didik akan diajak ke lokasi yang berada di luar sekolah yaitu lingkungan sekitar. Metode ini juga memerlukan perencanaan dengan persiapan yang matang. Terkait hal ini, seorang guru PAI harus jauh-jauh hari membuat perencanaan yang matang untuk pelaksanaan metode karyawisata. Selain itu, dalam karyawisata seringkali unsur rekreasi menjadi prioritas dari pada tujuan utama, sedangkan unsur studinya terabaikan. Metode ini juga memerlukan pengawasan yang lebih ketat terhadap setiap gerak gerik anak didik di lapangan. Dalam hal pembiayaan, biayanya metode ini cukup mahal karena proses pembelajarannya dilakukan di luar kelas dengan mengujungi tempat-tempat wisata. Metode ini juga 
membutuhkan tanggung jawab guru dan sekolah atas kelancaran karyawisata dan keselamatan anak didik, terutama karyawisata jangka panjang dan jauh.

Meskipun demikian, menurut responden, respon peserta didik ketika mengikuti pembelajaran cukup aktif karena semua peserta didik saling bertanya tentang objek-objek yang dibahas. Selain itu, guru yang mengajar menegaskan bahwa metode karyawisata dapat memberikan dampak positif terhadap hasil belajar peserta didik. Peserta didik dapat memiliki pengalaman baru tentang materi pelajaran dan pengalaman tersebut bisa tertanam dalam daya ingat mereka lebih lama, serta melatih peserta didik untuk bisa belajar mandiri. Dengan metode karyawisata ini peserta didik dapat memperoleh pengalaman langsung dari objek yang dilihatnya, menghargai dan menghayati tugas pekerjaan orang lain, serta membentuk pribadi yang bertanggung jawab. Melalui hal-hal tersebut, peserta didik juga akan mampu memecahkan persoalan yang dihadapinya dalam pelajaran, ataupun pengetahuan umum. Mereka bisa melihat, mendengar, meneliti dan mencoba apa yang dihadapinya agar nantinya dapat mengambil kesimpulan dan pada waktu yang sama mereka bisa mempelajari beberapa mata pelajaran.

Dengan demikian, pembelajaran PAI dengan metode karyawisata mendukung tujuan pendidikan Islam. Pendidikan Islam lebih khusus ditekankan untuk mengembangkan fitrah keberagaman dan sumber daya insani agar lebih mampu memahami, menghayati, dan mengamalkan ajaranajaran agama Islam dengan baik untuk memperoleh keselamatan hidup di dunia dan di akhirat. Oleh karena itu, akan diperoleh generasi-generasi muda yang unggul cerdas, mandiri, dan berakhlak mulia.

\section{Kesimpulan}

Hasil penelitian ini menunjukkan bahwa metode karyawisata dalam pembelajaran pendidikan agama Islam di TK Al-Fitrah Pekanbaru telah dilaksanakan secara teratur satu kali dalam sebulan dan sesuai tema yang diajarkan. Karyawisata yang dilaksanakan di museum, agrowisata, kebun sayur, kebun binatang, dan tempat kuliner dapat memberikan pengalaman langsung bagi peserta didik dari objek yang dilihatnya, menghargai dan menghayati tugas pekerjaan orang lain, serta membentuk pribadi yang bertanggung jawab. Meskipun metode karyawisata memiliki kelebihan dan kelemahan, pelaksanaannya dalam pembelajaran PAI telah memberikan manfaat yang sangat penting.

\section{Daftar Pustaka}

Arifin, M. (2008). Ilmu pendidikan Islam: Tinjauan teoritis dan praktis berdasarkan pendekatan interdispliner. Jakarta: Bumi Aksara. 
Daradjat, Z. (2017). Ilmu pendidikan Islam. Jakarta: Bumi Aksara.

Djamarah, S. B., \& Zain, S. (2006). Strategi belajar mengajar. Jakarta: Rineka Cipta.

Tafsir, A. (2011). Metodelogi pengajaran agama Islam. Bandung: Remaja Rosdakarya.

Saputra, A. (2019). Penerapan metode karyawisata dalam meningkatkan kemampuan menulis puisi pada mahasiswa pendidikan guru sekolah dasar Universitas Borneo Tarakan. Jurnal Pendidikan Dasar Borneo, 1(1), 113.

Saputri, W. I. (2017). Hubungan antara metode karyawisata dengan pembentukan karakter mandiri anak usia dini di PAUD Al-Baitul Amien Jember. Skripsi tidak dipublikasi. Jember: Universitas Jember.

Shidqiyah, S. (2019). Urgensi metode karya wisata terhadap pengembangan imajinasi dan kreatifitas anak iusia dini. Jurnal Kariman, 7(2), 255-264.

Usaha, L., Inah, E. N., \& Kadir, F. (2018). Meningkatkan hasil belajar IPA melalui model koperatif Number Head Together pada siswa kelas III B Madrasyah Ibtidaiyah Negeri II Konawe Selatan. Al-Ta'dib, 11(2), 146163.

Yati, P. (2016). Pendidikan karakter anak usia dini melalui metode pembelajaran field trip. Lentera, 18(1), 123-139. 